\title{
The Ecology of Extinctions in Kelp Forest Communities
}

\author{
JAMES A. ESTES \\ U.S. Fish and Wildlife Service \\ Institute of Marine Sciences \\ University of California \\ Santa Cruz, CA 95064, U.S.A.
}

\section{DAVID O. DUGGINS}

Friday Harbor Laboratories University of Washington Friday Harbor, WA 98250, U.S.A.

\section{GAIEN B. RATHBUN}

U.S. Fish and Wildlife Service P.O. Box 70

San Simeon, CA 93452, U.S.A.

\begin{abstract}
We recognize three levels of extinction - global, local, and ecological - and provide examples of each. The protection and recovery of sea otters (Enhydra lutris) bas provided abundant evidence of the consequences of their local extinction from kelp forest communities in the Nortb Pacific Ocean. These consequences include release of benthic invertebrate populations from limitation by predation; de. forestation of kelp beds due to increased grazing by berbivorous sea urchins, one of the otter's main prey; and various cascading effects resulting from the biological and pbysical importance of kelp in coastal ecosystems. These interactions probably were important agents of selection for certain species.
\end{abstract}

Two other examples are discussed: Steller's sea cow (Hydrodamalis gigas), a case of global extinction, and spiny lobsters, a possible case of ecological extinction. We speculate that grazing by sea cows was an important disturbance to surface-canopy-forming kelps and otber algae in the littoral zones, but also point out that any sucb interactions proba. bly acted in concert with physical disturbances by ocean waves. The ecological and evolutionary importance of sea cow grazing probably will remain a matter of speculation and conjecture because the species is globally extinct.

Predation by spiny lobsters limits a variety of littoral and sublittoral invertebrate populations, particularly mollusks. In one remarkable example, the reduction or local extinction of spiny lobsters enabled predatory whelks to increase in size and abundance, ultimately resulting in a predatorprey role reversal. From these and otber case studies we con252
Resumen: Reconocemos tres niveles de extinción: global, local y ecológica, y proporcionamos ejemplos de cada una.

La protección y recuperación de nutrias marinas (Enhydra lutris) ba proveido evidencia abundante sobre las consecuencias de su extinción local en comunidades de algas marinas-bosques de kelp-en el norte del Océano Pacífico.

Estas consecuencias incluyen la liberación de poblaciones de invertebrados (bentónicos) de su limitación por la caza por parte de la nutria marina; la deforestación de áreas con kelp debido al aumento del pastoreo por los pepinos de mar berbivoros, una de las principales presas de la nutria marina; $y$ varios efectos en "cascada." Estas interacciones ban sido, probablemente, agentes importantes de selección para ciertas especies.

Discutimos dos ejemplos más: la vaca marina de Steller (Hydrodamalis gigas), que representa un caso de extinción global, y la langosta espinoza, que posiblemente representa un caso de extinción ecológica

Especulamos que el pastoreo de las vacas marinas ba per. turbado de manera importante al dosel superficial de los bosques de kelp y a otras algas en las áreas litorales, pero asimismo señalamos que tales interacciones actuaron probablemente en conjunto a disturbios físicos causados por el oleaje marino.

La importancia ecológica y evolutiva del pastoreo de las vacas marinas seguirá siendo, probablemente, un tema deespeculación y conjetura, dado que dicha especie está extinta a nivel global. 
clude that (1) the extinction of consumers may bave broad, and sometimes unexpected, influences on kelp forest ecosys. tems; (2) direct or indirect interactions with now-extinct species probably exerted important selective influences on many extant forms; (3) sucb ecological and evolutionary influences are best understood where local or ecological extinctions, followed by recoveries, bave provided comparisons in space or time; and (4) because of various ecological and behavioral barriers, local extinctions and their ecological consequences may not be simply reversed by protecting or reintroducing depleted or locally extinct species.

\section{Introduction}

Ecologists have traditionally interpreted patterns observed in natural populations or communities based on extant physical and biological processes. Historical events also can have important influences on natural communities, although they may be difficult to assess unless they recur and are observed, or unless they leave other clues in the historical record. Extinctions are historic events that have occurred at varying rates through geological time (Berggren \& VanCouvering 1984; Valentine 1985). Pleistocene and Recent human-caused extinctions also are known or suspected (Martin 1973; Martin \& Klein 1984), and although species are being lost at ever-increasing rates because of human exploitation or habitat destruction, the consequences of these losses are understood poorly, if at all.

Just as all species vary in their importance to the organization of their extant communities, so must it be that extinctions have been of varying importance in shaping extant communities. By definition (Lewontin 1969), the loss of a species sets its community at another "boundary point." However, unless that species interacts significantly with other species in the community (e.g., it is an important predator, competitor, symbiont, mutualist, or prey), its loss may result in little or no adjustment to the abundance and population structure of other species. At the other extreme are species that interact significantly in communities with strongly linked food webs (Paine 1980); the loss of such a spe-
La predación de langostas espinozas limita a una var. iedad de poblaciones de invertebrados, litorales y sublitorales, particularmente a moluscos.

En un ejemplo admirable, la reducción o extinción local de langostas ba permitido a las conchas univalvas espirales (wbelks) incrementar su tamaño y abundancia, dando por resultado a una inversión del rol predador-presa.

En base a éstos y otros estudios, podemos concluir que

(1) La extinción de consumidores puede tener vastas $y$, algunas veces, inesperadas influencias en ecosistemas de bosques de algas marinas (kelp).

(2) Probablemente, interacciones directas o indirectas con especies boy en día extintas ejercieron influencias selectivas sobre muchas formas existentes.

(3) Estas influencias ecológicas y evolutivas se entienden mejor en aquellos casos donde extinciones locales o ecolog. icas, seguidas de una recuperación, han proporcionado com. paraciones en tiempo o en espacio.

(4) Debido a numerosas barreras ecológicas y conductuales, las extinciones locales y sus consecuencias ecológicas no pueden ser invertidas simplemente protegiendo o reintroduciendo especies disminuídas o extintas localmente.

cies may cause substantial adjustments in the abundance and population structure of other species in the community, including further extinctions.

We recognize three classes of extinctions in this paper: (1) global extinction - the ubiquitous disappearance of a species; (2) local extinction - the disappearance of a species from part of its natural range; and (3) ecological extinction - the reduction of a species to such low abundance that, although it is still present in the community, it no longer interacts significantly with other species.

We discuss the ecological consequences of extinctions in kelp forest ecosystems by describing three case studies. The first and best known of these is that of the sea otter (Enbydra lutris). We summarize the known direct and indirect influences of sea otter predation in North Pacific kelp forest ecosystems, speculate on possible evolutionary effects of these interactions, and show how local extinctions and recoveries served as natural field experiments that led to these discoveries. Next, we discuss two other cases in less detail - those of the spiny lobster (Panuluris interruptus in the eastern North Pacific and Jasus lalandii in the eastern South Atlantic) and Steller's sea cow (Hydrodamalis gigas in the North Pacific). We conclude with some general comments on the ecological and evolutionary importance of extinctions in kelp forest systems; with an examination of the circumstances under which the importance of extinctions is likely to be understood; and by pointing out why local extinctions may not be easily reversible through reintroductions or other conserva- 
tion measures because of various behavioral and ecological barriers.

\section{Case Studies of Extinctions}

\section{Sea Otter - Local Extinction}

Sea otters once ranged across the Pacific rim from northern Japan to central Baja California (Kenyon 1969). The species apparently was hunted to extinction in small areas by aboriginal people (Simenstad et al. 1978 ), but the Pacific fur trade, which began with Vitus Bering's expedition to North America and the Aleutian Islands in 1741, marked the beginning of large-scale extirpations. By the beginning of the twentieth century sea otters had been eliminated from most of their natural range. Small remnant colonies survived at 13 known locations, some of which later dwindled to extinction (Kenyon 1969). After protection was imposed in 1911 by an international treaty, several of these remnant colonies began to increase. By the late 1930s or 1940s large populations again occurred at several islands in the western and central Aleutian archipelago, and by the early 1970 s sea otters were at or near equilibrium density at numerous islands in the Aleutian and Kuril archipelagos. Other isolated island groups, and most of the shoreline of continental North America, remained uninhabited. Some of these areas are now being recolonized.

The ecological consequences of local sea otter extinc. tions are known from spatial comparisons of areas with and without sea otters, or from temporal changes that have followed the species' recolonization.

\section{DIRECT EFFECTS}

Sea otters feed on a host of benthic invertebrate species (Kenyon 1969; Estes et al. 1981). The direct effect of otter extinctions was that populations of many of these invertebrates were released from limitation by predation, which changed their abundance and size structure. There is evidence from numerous studies that the extinction of sea otters caused population increases in a wide variety of invertebrates, including echinoids, gastropods, bivalves, and decapods (reviewed by Estes \& VanBlaricom 1985; VanBlaricom \& Estes 1988). Several recent examples are Laur et al.'s (1988) finding that the densities of red sea urchins (Strongylocentrotus franciscanus) and purple sea urchins (S. purpuratus) declined to nearly zero after the arrival of sea otters near Point San Luis, California; the finding by Wendell et al. (1986) that the recreational catch of Pismo clams (Tivela stultorum) declined to zero after the arrival of sea otters at Pismo Beach, California; and the report by Garshelis et al. (1986) that the commercial fishery for Dungeness crab (Cancer magister) collapsed following the arrival of sea otters in eastern Prince William Sound, Alaska. Estes \& Palmisano (1974) and Estes et al. (1978) argued that the extinction of sea otters influenced the size distribution of populations of the green sea urchin (Strongylocentrotus polyacanthus) in the western Aleutian Islands by pointing out that urchins with test diameters greater than about $35 \mathrm{~mm}$ are almost never found at islands with sea otters, whereas urchins with test diameters from about $50-85 \mathrm{~mm}$ compose most of the biomass at islands lacking sea otters. Selection by otters of the largest sea urchins is the mechanism most likely responsible for these differences (J.A. Estes \& D. O. Duggins, in preparation).

\section{INDIRECT EFFECTS}

Most of the known or suspected indirect consequences of the extinction of sea otters are those resulting from the release from predation, and thus population increases, of herbivorous echinoids. Strong interactions (sensu Paine 1980) seem to occur between many elements of the food web in kelp forest ecosystems. Because sea otters limited sea urchins and sea urchins can limit populations of fleshy macroalgae (see reviews by Lawrence 1975 and Harrold \& Pearse 1987), and because kelp beds influence nearshore communities in a variety of important ways (Mann 1982; Duggins 1988), the local extinction of sea otters had cascading effects of broad influence in kelp forest ecosystems. The primary indirect consequence of the local extinction of sea otters was the reduction of kelp and other fleshy macroalgae due to increased grazing intensity by sea urchins. Although other factors, such as physical disturbance, can directly affect algal populations (Dayton et al. 1984; Foster \& Schiel 1988), evidence from a wide range of locations along the northeastern Pacific leaves little doubt about the importance of sea otters in structuring kelp-dominated communities (VanBlaricom \& Estes 1988). For example, samples taken in 1987 from a large number of randomly selected locations ( 128 sites, 2,377 quadrats) in the western and central Aleutian Islands showed that kelp beds or deforested habitats were respectively correlated (with $>95$ percent certainty) with the presence or absence of sea otters (J. A. Estes \& D. O. Duggins, in preparation). Similar sampling programs recently completed or under way in southeast Alaska (J. A. Estes \& D. O. Duggins, in preparation; J. A. Estes, G. R. VanBlaricom, \& D. Carney, unpublished data) and British Columbia (J. Watson \& J. A. Estes, unpublished data) are revealing similar patterns. We (Estes and Duggins) recently resampled five study sites in Torch Bay, Alaska, which in the late 1970s, before the arrival of sea otters, were extensively deforested by red, purple, and green ( $S$. drobachiensis) sea urchins (Duggins 1980). Several hundred sea otters recolonized Torch Bay in 1986-87. By 1988 kelp beds had come to dominate these sites (and all others we sampled), and we had difficulty locating any living sea urchins. 
Reductions in the abundance of kelp and other macroalgae that accompanied local extinctions of sea otters are known to influence or are suspected of influencing other species of consumers in Pacific kelp forests. Various fishes are linked to kelp beds (Quast 1971a, b; Ebeling \& Laur 1988; Bodkin 1988). The larger nearshore fishes, most notably rock greenling (Hexagrammos lagocephalus) in the Aleutian Islands, are one to two orders of magnitude more common where kelp beds were present than where they were absent (C.A. Simenstad, J. A. Estes, \& R. K Cowen, unpublished data). This interaction, in turn, seems to influence the foraging economics of other species. For example, Glaucouswinged Gulls (Larus glaucescens) fed largely on intertidal invertebrates at Attu Island (sea otters sparce or absent), whereas they fed mainly on fish at Amchitka Island, where sea otters are abundant (Irons et al. 1986). Similarly, sea otters fed almost exclusively on invertebrates at Attu Island and extensively on fish at Amchitka Island (Estes et al. 1981). Furthermore, foraging effort by sea otters was distributed uniformly through the day at Attu Island but peaked near dawn and dusk at Amchitka Island - patterns consistent with temporal variation in availability of the different prey groups (Estes et al. 1982).

We (D. O. Duggins, C. A. Simenstad, and J. A. Estes) have begun to look at the importance of kelp production in coastal ecosystems in the central and western Aleutian Islands where most of the production comes from a marine system in which fleshy macroalgae and phytoplankton are the two main primary producers. For reasons not yet fully understood, these plant groups fix the stable isotopes of carbon, ${ }^{12} \mathrm{C}$ and ${ }^{13} \mathrm{C}$, in different ratios. By comparing the ratio of these isotopes in a variety of consumer species between islands with and without sea otters, we found that, on average, 75 percent (range 20-80 percent) of the organic carbon is derived from kelp production at islands with abundant sea otter populations, whereas at islands lacking sea otters the relative importance of kelp versus phytoplankton is reversed (Duggins et al., 1989). These results indicate that local extinctions of sea otters significantly affected primary production and food web structure in at least some coastal communities.

\section{BVOLUTIONARY EFFECTS}

The evolutionary effects of sea otter predation are largely unknown. Yet it is likely, if not inevitable, that a species involved with such strong and broad-ranging interactions had selective influences on other species in the community.

Estes \& Steinberg (1988) argued that predation on herbivores by sea otters, their ancestors, and perhaps other species of benthic-feeding marine mammals, influenced the evolution of kelps (order Laminariales) by creating an environment in which the intensity of herbivory was low. The kelps probably radiated in the North Pacific late in the Cenozoic because (1) the diversity of extant taxa is greatest there, and (2) only since the late Tertiary have water temperatures in the North Pacific been low enough to allow the existence of any extant kelp species. These conditions should have selected for species that were good competitors but poorly defended against herbivores, an idea supported by Steinberg's (1989) finding that both the variety and amount of known defensive secondary compounds are low in North Pacific kelps, compared with kelps and rockweeds (order Fucales) from the cool southwestern Pacific Ocean where sea otters or their analogues are absent. If this scenario is true, the evolutionary history of kelp communities figures prominently in explaining the extensive deforestation of kelp beds that occurs in many parts of the cool temperate to subarctic North Pacific Ocean. Thus, following the large-scale extinction of sea otters, the kelps (and perhaps other marine plants) were subjected to intensities of herbivory that far exceeded those that had occurred during their late Tertiary evolution in the North Pacific Ocean

\section{RECOVERY AND CONSERVATION OF SEA OTTBRS AND THE NEAR-SHORE COMMUNITY}

Conservationists and wildlife managers have been endeavoring to reestablish sea otters in various parts of their now unoccupied natural range. Because of the limited capacity of this species for natural dispersal, reestablishment has sometimes required reintroductions. We next review some of what has been learned in these relocation efforts, and in studies of sea otter populations and near-shore communities during the process of recovery.

Most of the sea otter's historical range appears suitable for recovery of the species, despite pollution, shooting, and entanglement in fishing gear. Most of the coastal habitat from Prince William Sound, Alaska, westward to Kamchatka and the Kuril Islands has been recolonized, and populations are probably at or near equilibrium density in much of this area. Besides occasional surveys or anecdotal reports (summarized by Kenyon [1969]), little is known about the rate at which these populations recovered, the patterns of range expansion, or the temporal patterns of change in benthic communities that accompanied these recoveries. More useful information is available from recent natural recolonizations (Attu Island) or from reintroductions to southeast Alaska, British Columbia, Washington State, Oregon, and San Nicolas Island in the southern California Bight. Population changes have been documented at each location by periodic or occasional surveys. The methods and data are from Jameson et al. (1982, 1986), Brownell \& Rathbun (1988), Estes (manuscript), and unpublished records of the U.S. Fish and Wildlife Service. 
Two patterns are seen in these data (Fig. 1). First, once established, the rate of increase for each population has been 17-20 percent per year. This rate, estimated from the least squares best fit of $\ln$ population counts versus time, probably represents the maximum rate of increase ( $r_{\max }$, sensu Caughley [1977]) for the species in its natural environment. Such high rates of increase lend further support to the argument that most of the unoccupied range of the sea otter is highly suitable for the species' recovery. Second, as noted by Jameson et al. (1982), the reintroduced colonies declined substantially after the animals were released into the new environments. Although the number of animals released in each translocation is known, the exact patterns of decline are difficult to ascertain because follow-up surveys were not done for several years, except in Oregon and at San Nicolas Island. The Oregon population was surveyed one year after reintroduction, and at San Nicolas Island there has been an intensive and almost continual monitoring effort. We have estimated postrelease population declines for southeast Alaska, British Columbia, and Washington by extrapolating the growth regressions back in time to one year after each reintroduction (where reintroductions were done over several years, we have estimated population size one year after most of the animals were moved - see Jameson et al. [1982]). These data and analyses indicate that at best about one-third of the animals remained in the relocated colony after one year (Table 1 ). Declines were considerably greater (to about 7-23 percent of the initial col-

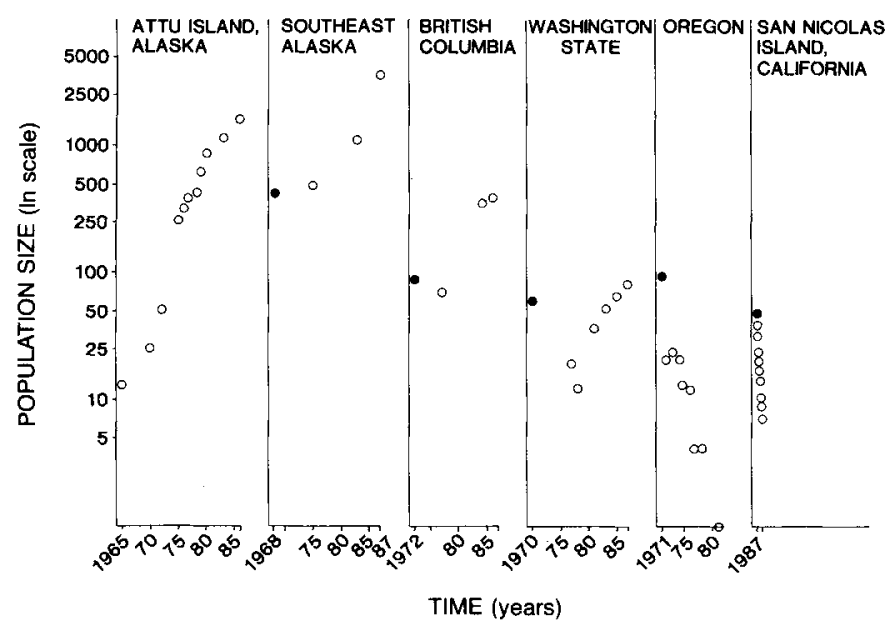

Figure 1. Population trends in six recently reestablished sea otter populations. The Attu population is a natural recolonization; all others were reestablisbed by relocations. Open circles are counts from population surveys. Darkened circles represent numbers of animals relocated. Note that counts at San Nicolas Island were done at one-month intervals whereas one year or longer intervals separate counts from the other five locations.
Table 1. Declines in reintroduced sea otter populations. $N_{t}=$ numbers of animals relocated; $\mathbf{N}_{t+1}=$ observed or estimated one year later.

\begin{tabular}{|c|c|c|c|}
\hline & $\begin{array}{l}\text { Number } \\
\text { Released }\end{array}$ & $\begin{array}{c}\text { Estimated or } \\
\text { observed number } \\
1 \text { year later }\end{array}$ & $N_{t+1} / N_{t}$ \\
\hline Southeast Alaska & 412 & $150 \dagger$ & .364 \\
\hline British Columbia & 89 & $28 \dagger$ & .315 \\
\hline Washington State & 59 & $4 \dagger$ & .068 \\
\hline Oregon & 93 & $21^{*}$ & .226 \\
\hline $\begin{array}{l}\text { San Nicolas } \\
\text { Island }\end{array}$ & 47 & $7^{*(10}$ mths $)$ & .149 \\
\hline
\end{tabular}

* Observed

† Estimated from population growth curves

ony) in Washington, Oregon, and at San Nicolas Island. The rate of decline at San Nicolas Island appears to have been roughly constant during the first 10 months after release (Fig. 1).

A preliminary analysis of the results from studies at San Nicolas Island has shown that the decline of sea otters at this site is at least partly and perhaps largely a result of animals leaving the island. Since all the sea otters released at San Nicolas Island were individually marked with unique flipper-tag combinations, we known which ones stayed, which ones left, and the fate of some of those that dispersed. Of the first $\mathbf{5 0}$ sea otters taken to San Nicolas Island during August and September 1987, 3 are known to have died of stress at the island soon after release. There has been a distinct tendency for the larger animals to leave. Of the remaining 47,18 (38 percent) weighed $40 \mathrm{lbs}$. or more. Of the 8 animals known to have stayed at the Island through June 1988 (9 months), only 1 ( 14 percent) weighed 40 lbs. or more at the time of capture. By August 1988, 10 of the 14 animals known to have left San Nicolas Island had been resighted back within the mainland range of sea otters in central California. Others, as yet unidentified, no doubt have returned as well. Of the 10 known returnees, 5 were resighted within about 1 mile of the point of initial capture; 4 of these 5 animals weighed 40 lbs. or more when initially captured.

We had presumed that, because of the isolated location of San Nicolas Island and the abundant invertebrate food, most of the relocated sea otters would remain there, even if not all survived. This was clearly an incorrect presumption. It is now known that sea otters are capable of crossing the 25 miles or more of open sea separating San Nicolas Island from the nearest other island (Santa Barbara Island), or the nearly 70 miles to the mainland coast, and then navigating the ca. 200 miles along the coast to their capture locations in central California. These observations indicate that sea otters, for whatever reasons, have a strong home range fidelity that creates a behavioral barrier to their reestablishment by reintroductions. The barrier is strengthened by the even stronger tendency to disperse in subadults and sexually 
mature adults than in juveniles, thus preventing the immediate reestablishment of a translocated population with any reproductive potential. Homing behavior is not unique to sea otters; it has been found to be a problem in establishing reintroduced populations of many other mammals, including the black bear (Ursus americanus), wolf (Canis lupis), and pronghorn (Antilocapra americana), to mention only a few (Boyer \& Brown 1988, Rogers 1988).

We now shift to a brief discussion of community changes that have accompanied the reestablishment and growth of sea otter populations. These data are being analyzed and are to be discussed in more detail elsewhere (Estes \& Duggins, in preparation). Here we compare temporal changes in echinoid and macroalgal populations after the reestablishment of sea otters at two sites in Alaska: Attu Island, westernmost of the Aleutians, and the outer coast of southeast Alaska near Cape Spencer.

We have been working at Attu Island since the early 1970s and have data on kelp abundance and the density and size distribution of sea urchins from sites that have been occupied by otters since that time, as well as from sites that were occupied more recently. In most instances, the reestablishment of sea otters was followed within a year or so by the loss of virtually all large sea urchins from the population (Fig. 2). However, the density of sea urchins increased, perhaps as a result of reduced intraspecific competition. And despite the reduction of large sea urchins, deforested habitats remain in most areas; in contrast with our expectations, kelps and other macroalgae have not recovered. Two of the study sites at Attu have been within the otter's range and have persisted in this configuration for at least 15 years. It appears that the behavior of this system is driven by at least two important influences: the frequent, predictable, and heavy recruitment of sea urchins; and selection by sea otters of the larger urchins. Evidence for heavy and frequent recruitment (i.e., large numbers of animals $<15 \mathrm{~mm}$ test diameter) has been found at virtually all areas and times that we have sampled in the western and central Aleutian archipelago (Estes \& Duggins, in preparation). Depending on the presence or absence of sea otters, sea urchin size distributions are typically as shown in Fig. 2. We have estimated the size distributions of urchins eaten by otters from the remains of urchin demipyramids in otter scats. The method is similar to that used by Simenstad et al. (1978). These data indicate a preference by otters at Attu Island for sea urchins $>$ about $30 \mathrm{~mm}$ test diameter (Fig. 3). Apparently as sea otter populations grow toward equilibrium levels, as indicated by the data from Amchitka and Adak islands (Fig. 3), smaller urchins are eaten, although the otters continue to prefer animals $>$ about $20 \mathrm{~mm}$ diameter. Thus, with the reestablishment and growth of sea otter populations, the system in the western Aleutian

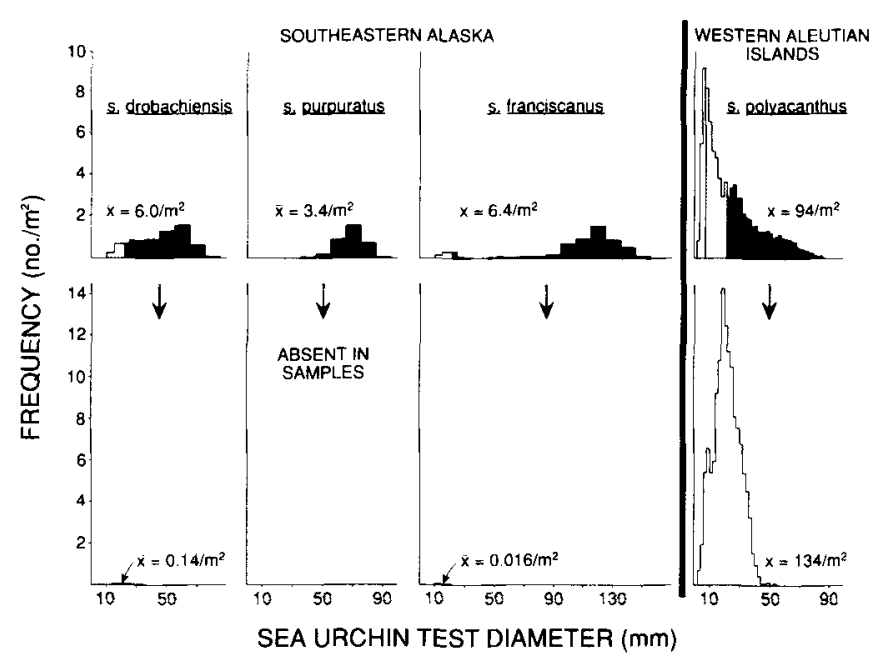

Figure 2. Size frequency distributions of sea urchins before (top panels) and after (bottom panels) they were exploited by sea otters. The southeast Alaska data are from five sites in Torch Bay, surveyed in the late 1970s (before the arrival of sea otters) and again in 1988 (two years after the arrival of sea otters). The western Aleutian Islands data contrasts Alaid, Shemya, and Nizki Islands (otters absent) with nearby Attu Island (otters present for about 20 years). Sbaded, batched, and open sections of frequency distributions in the upper panels respectively represent (1) > modal size eaten by sea otters; (2) < modal size eaten by sea otters; and (3) < minimum size eaten by sea otters (see Fig. 3).

Islands apparently behaves in the following way: The largest sea urchins are removed soon after arrival of the otters. However, heavy and predictable sea urchin recruitment, coupled with the otter's preference for larger sea urchins, provides smaller urchins with a refuge from predation. High densities of small urchins, sufficient to prevent reestablishment of fleshy macroalgae, persist despite the otter's presence. Although we have not yet followed the system from otter reestablishment to equilibrium density, we suspect that it remains deforested by sea urchin grazing until the otters become limited by competition for food. Judging by data from Amchitka and Adak islands, otters begin at this point to feed on smaller sea urchins, the density and biomass of sea urchins are reduced and the intensity of herbivory is consequently reduced, and kelp beds eventually recover (Fig. 4). This process may require several decades.

The system in southeast Alaska behaves very differently. Although high densities of three urchin species persist in the absence of sea otters (Fig. 2), individuals $<15 \mathrm{~mm}$ diameter are rare or absent from populations of each species, thus indicating that recruitment is light or infrequent, compared with that in the western and central Aleutians. Presumably sea otters select similarly sized sea urchins in southeast Alaska and the western 


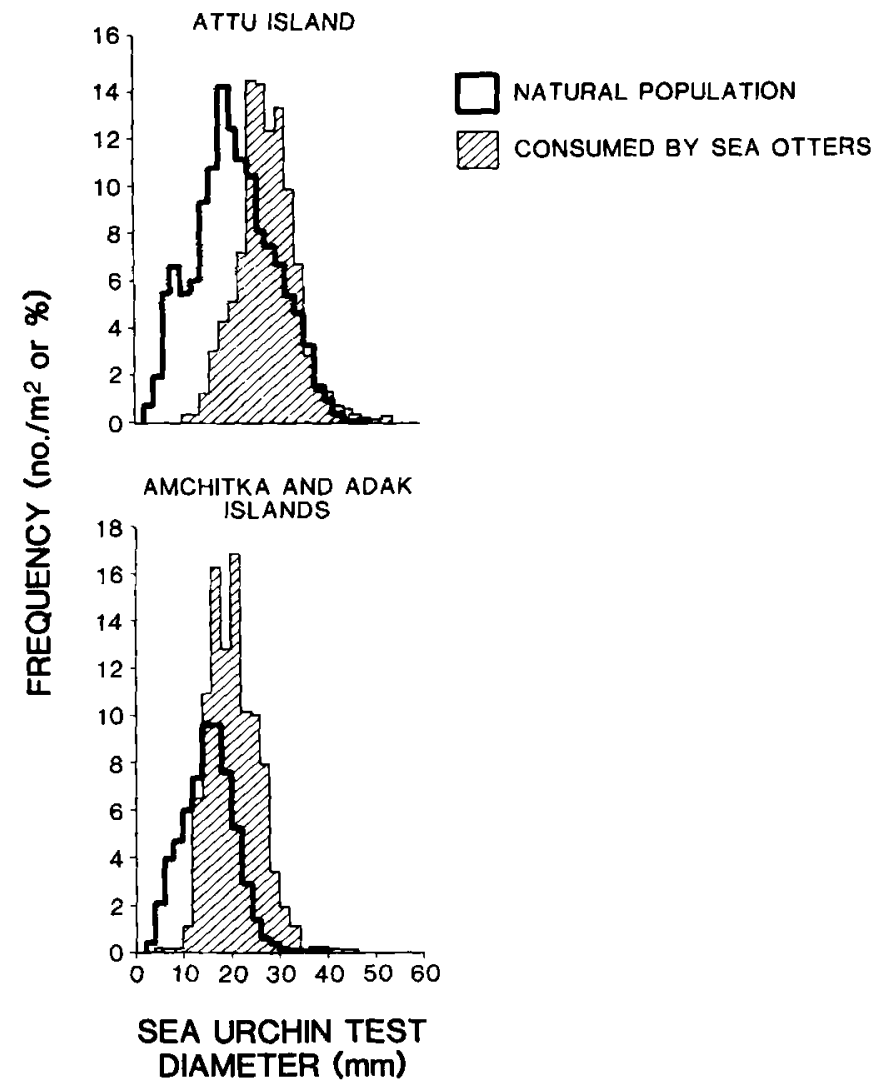

Figure 3. Size frequency distributions of sea urchins in natural populations (open histograms) and eaten by sea otters (batched bistograms) at Attu Island (sea otter population below equilibrium density) and Amcbitka and Adak islands (sea otter popula. tions at or near equilibrium density). Sizes of urchins eaten by otters were determined by measuring the length of demipyramids in otter scats collected from Attu, Amchitka, and Adak islands. Urchin test diameters were estimated from demipyramid length by $Y=-5.9484+5.7132 \times$ (from Simenstad et al. 1978) where $Y=$ urchin test diameter $(\mathrm{mm})$ and $X$ $=$ demipyramid length $(\mathrm{mm})$.

Aleutians, although there are no data from southeast Alaska. With the reestablishment of sea otters, changes in sea urchin populations have been immediate and profound. Purple urchins were effectively driven to extinction, and the densities of red and green sea urchins were reduced to 0.25 percent and 2.33 percent, respectively, of the number there before the otter's arrival (in contrast, numbers increased $\mathbf{4 2 . 5}$ percent at Attu Island). Echinoid herbivory in southeast Alaska was effectively eliminated, allowing the rapid proliferation of kelp beds (Fig. 4). Thus, temporal patterns of community change in response to the reestablishment and growth of sea otter populations differ fundamentally between the Aleutian Islands and southeast Alaska, perhaps largely because the herbivores have different recruitment pat-

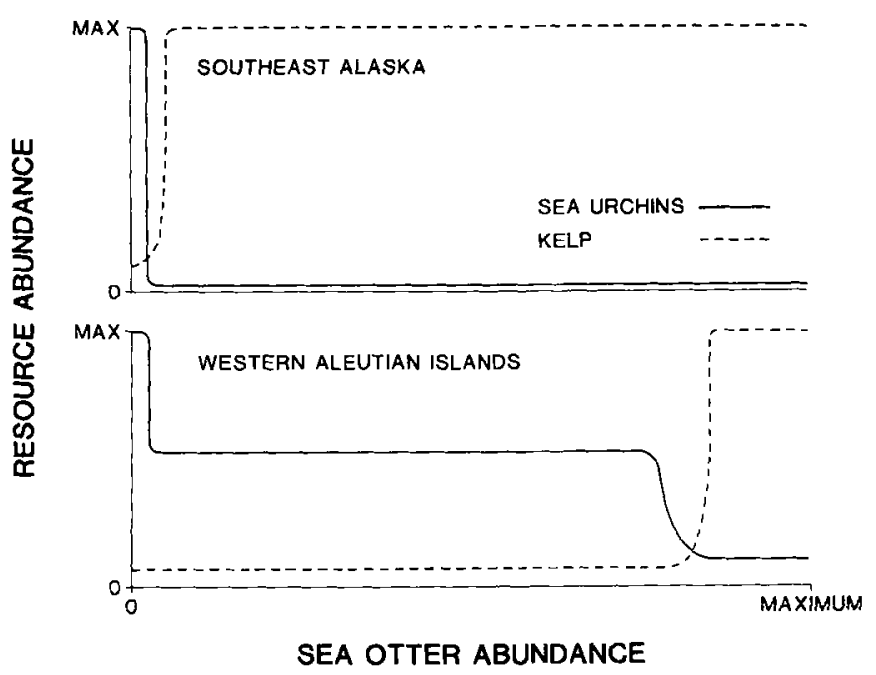

Figure 4. Scbematic representation of community changes on the rocky benthos in the western Aleutian Islands and soutbeast Alaska with the reestablishment of sea otters and their population growth to an eventual equilibrium density.

terns. Frequent sea urchin recruitment, coupled with size-selective predation by sea otters, appears to provide a temporary ecological barrier to recovery of the kelp forest community.

Although more speculative than the interactions just described, there is evidence that sea otter populations in some areas exist at multiple equilibrium densities. This possibility is suggested by the pattern of population recovery at Amchitka Island (Fig. 5). Although a rem. nant population survived at Amchitka, it contained only a few animals at the start of this century. From observations made at other Aleutian Islands where otters are rare or absent, we presume that the rocky benthos surrounding Amchitka Island was largely deforested by sea urchin grazing at that time (anecdotally supported by observations of Aleuts who lived at Amchitka early in

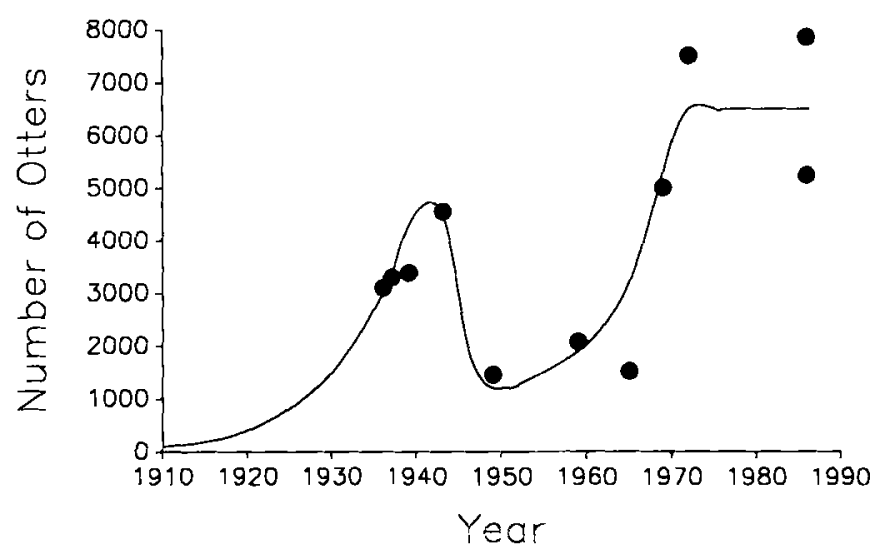

Figure 5. Long-term population trends of the sea otters at Amchitka Island, Alaska Data are population counts; solid line drawn by eye. 
this century - Kenyon [1969]). This situation may, in fact, have persisted for a century or more if sea otters at Amchitka were hunted to low levels early during the fur trade. In any case, it seems likely that the otters that survived there into this century fed in an environment in which benthic invertebrates were plentiful and kelp bed fishes were rare. Observations from Attu (J. Estes, unpublished data) suggest that as the otter population at Amchitka Island began to increase, the rocky benthos remained largely deforested by sea urchin grazing. The otter population at Amchitka peaked in the early $1940 \mathrm{~s}$ (about 3,500 were counted, from which about 4,500 were estimated - Kenyon [1969]), and thereafter declined to perhaps one-half to one-third this number. The population subsequently increased again, and by the early 1970s had reached 5,000-8,000, where it now remains (Estes, manuscript). Inasmuch as many otters starved (Kenyon 1969), presumably there was intense competition for food when the population peaked and declined in the 1940s. The sizes of sea urchins selected by otters probably shifted to include smaller individuals during this time (as suggested in Fig. 3), thus reducing sea urchin density and increasing kelp beds and associated populations of kelp bed fishes. Sea otters apparently did not feed extensively on fish until sometime after the population declined in the early 1940s (Estes et al. 1978,1982 ). Thus, the inclusion of fish in the sea otter's diet may reset the equilibrium population size to a level well above that attainable on a diet of invertebrates alone.

It is intriguing to further speculate that perhaps learned behavioral skills required for foraging on fish were lost to local populations when the species was reduced to a few remnant colonies at the end of the fur hunting era. Because benthic invertebrates probably were common compared with fish when otter populations were low, the economics of prey choice may have excluded fish from the otter's diet under those circumstances. Studies of prey choice in California show highly individualistic diets (Lyons 1989), which may be matrilineally inherited (by learning) from mother to pup ( $M$. Riedman, unpublished data). If similarly individualistic diets occur in Alaska (they probably do; Estes et al. 1981 ), and if piscivory by sea otters requires search and capture skills substantially different from those required for feeding on benthic invertebrates, the behavioral in novations necessary for piscivory may recur only rarely in populations that have lost this behavior. Under circumstances where this behavior is cost-effective (i.e., when a population is food-limited, benthic invertebrates are rare, and fish are common), such an innovation, once discovered, might convey a large advantage to the individuals that adopted it. Since prey preferences in sea otters may be learned during the extended period of pup dependence (M. Riedman, unpublished data), piscivory could easily spread through the population. Al- though we have no direct evidence to support this idea, it would explain the time course of population change at Amchitka Island (Estes 1981), as well as the comparatively small sea otter population at Medny Island in the Commander Islands (i.e., about 1,000 animals at an island about the size of Amchitka), which appears to be food-limited but where otters do not feed on fish (A. Zorin, personal communication).

There are numerous well-documented accounts of behavioral innovation being spread through a population by imitative learning (Bonner 1980). Two commonly cited examples, which involve optimal foraging tactics, are the opening of milk bottles by blue tits (Parus caeruleus) in England (Hinde \& Fisher 1951) and potato and wheat washing by Japanese macaques (Macaca fuscata) in Japan (reviewed by Wilson 1975:170). Both of these examples involve individuals inventing or discovering innovative behaviors that allowed them to take advantage of a new food resource very similar to what we suggest may have occurred with sea otters and fish. If this idea is true (and we reiterate that it is speculative), it would explain the remarkable differences in sea otter density between populations that do not feed on fish (e.g., central California, Prince William Sound, Attu Island, and Medny Island) and those that do (e.g., Amchitka and Adak islands).

\section{Steller's Sea Cow - Global Extinction}

Steller's sea cow, a dugongid sirenian that lived in north Pacific kelp forest communities, was a strictly algivorous herbivore (Domning 1978). It was the last species in an old and reasonably well known lineage. The hydrodamalines apparently radiated northward from the tropical Pacific with polar cooling late in the Cenozoic. Presumably the earlier tropical dugongids fed extensively on marine angiosperms (Domning 1978), as does the extant dugong, Dugong-dugon (Marsh 1982). The late Cenozoic decline in marine angiosperms and radiation of the kelps in the North Pacific Ocean (Estes \& Steinberg 1988) was accompanied by a progressive reduction in the dentition of adult hydromalines (Takahashi et al. 1986) and an increased tendency for sea cows to feed on macroalgae (which do not contain the abrasive compounds found in marine angiosperms). Steller's sea cow apparently was abundant across the Pacific rim into the late Pleistocene, but probably declined abruptly over most of its range with the "discovery of America" (Martin 1973) and the development of aboriginal maritime hunting cultures (Domning 1972). The most compelling evidence for this idea is that (1) Steller's sea cows were abundant in the Commander Islands when Vitus Bering landed there in 1742 , but were extinct elsewhere, and (2) the Commander Islands are the only location within the sea cow's range that never were inhabited by aboriginal people. Steller's sea cows were 
so numerous in the Commander Islands that the early fur hunters made a special point of stopping there to take on fresh meat during trips further to the east; however, the species apparently was so vulnerable to hunters, and so highly sought after, that this last remnant population was driven to extinction by 1768,26 years after its discovery.

Because Steller's sea cow is globally extinct, it is possible only to speculate on its ecological importance in kelp forest communities. If the species was unable to dive, as suggested by Steller's direct observations (Stejeneger 1887) and Domning's (1978) morphological evidence, whatever influence it had as a grazer in kelp forest communities must have been limited to the surface canopy and littoral zones. At best, the animals probably could feed no more than several meters below the surface. There are four main surface canopy-forming kelps in the North Pacific: Macrocystis pyrifera and $\boldsymbol{M}$. integrifolia (giant kelps) range from about Prince William Sound to central Baja California; Nereocystis leutkeana (bull kelp) ranges from Umnak Island to north of Point Conception; and Alaria fistulosa ranges from near Kamchatka to the Queen Charloette Islands (Druehl 1969). Although Steller's sea cow may have fed extensively on these species, disturbance by sea cow grazing on the surface canopy must have acted in concert with physical disturbances from ocean waves. Thus it is difficult to attribute life history characteristics of any of these species as adaptations to sea cow grazing. If sea cow grazing constituted a significant cost to any of the surface canopy-forming kelps (beyond that incurred from physical damage by ocean waves) and if sea urchin populations were so small as to be an insignificant selective factor on kelps, one might expect the surface canopy kelps to be defended better than the epibenthic kelps against herbivores. But this does not appear to be true. Although some of the epibenthic kelps synthesize significant concentrations of secondary chemicals (phlorotannins) that are known to deter invertebrate grazers, all of the surface canopy kelps contain low concentrations of these compounds (Steinberg 1985). Furthermore, both Alaria fistulosa and Nereocystis leutkeana are competitively subordinate to the epibenthic kelps (Dayton 1975a; Duggins 1980). Thus it seems unlikely that sea cow grazing mediated competition between surface canopy and subcanopy kelp species, at least in boreal and subarctic regions.

The same may not have been true for kelp forests dominated by Macrocystis pyrifera in the temperate to warm-temperate waters of California and Baja California. Here this perennial species often has an important lightlimiting influence on the epibenthic canopy (Reed \& Foster 1984; Dayton et al. 1984). Macrocystis forests in central and southern California often are largely devoid of an epibenthic algal assemblage, the rocky benthos instead being covered with sessile suspension-feeding invertebrates. One can easily imagine that sea cow grazing opened the Marcrocystis surface canopy, allowing more light to penetrate to the sea floor. This interaction, which may have been especially prevalent during spring and summer when kelp growth is high and stormgenerated wave disturbance is low, might have driven Macrocystis-dominated communities toward increased abundance of epibenthic kelps and other macroalgae, and decreased the abundances of benthic suspension feeders. Similar arguments about the possible influence of sea cows can be made for epibenthic algae living in the littoral zones and at the sublittoral fringe (which, from the morphological and behavioral evidence, was perhaps the sea cow's main feeding habitat). These species are subjected to strong disturbances from ocean waves (Dayton 1973, 1975b; Paine 1979; Sousa 1979), effects that may have been largely complementary to sea cow grazing unless sea cows were selective foragers. Furthermore, disturbances from sea cow grazing may have been important throughout the year, whereas ocean wave disturbances are most important after autumn and winter storms. It is also intriguing to note that two surface-canopy kelps (Macrocystis spp. and Alaria fistulosa) bear their sporophylls near the bottom, whereas most of the epibenthic kelps distribute their reproductive tissues over the length of their blades. The sad fact is that the global extinction of Steller's sea cow took with it any possibility of obtaining direct evidence about its herbivorous role in kelp forest communities, or as a selective factor shaping kelp evolution.

\section{Spiny Lobsters - Ecological Extinction}

The California spiny lobster ranges from about Point Conception to central Baja California. This species is known to prey on various bivalves, gastropods, and echinoids as well as on animal detritus. The size and abundance of spiny lobsters have been greatly reduced throughout the range of the species by commercial and recreational fisheries (Duffy 1973). Tegner \& Dayton (1981) and Tegner \& Levin (1983) suggested that lobsters are important predators on sea urchins in subtidal communities, and Robles (1987) demonstrated experimentally that intertidal populations of mussels (Mytilus edulis and $M$. californianus) are limited by lobster predation in an area closed to fishing at Santa Catalina Island, California. These findings suggest that spiny lobsters may have been important predators in warmtemperate kelp forest communities before their populations were reduced by the fishery. Alternatively, if lobster populations were reduced by sea otter predation (our recent studies at San Nicolas Island have shown that sea otters eat lobsters), lobster predation may have been relatively unimportant when sea otters were still abundant south of Point Conception.

The South African spiny lobster has been shown by 
Barkai \& McQuaid (1988) to be an extremely important predator in kelp forest communities. In their study, subtidal communities were compared between two nearby islands, one where lobsters were absent and another where lobsters were abundant. Caged lobsters survived indefinitely at both islands, thus demonstrating the physical suitability of both islands for lobsters. Anecdotal evidence provided by local fishermen indicated that both islands supported abundant lobster populations until the early 1970s, but for reasons still unclear (local oxygen depletion was speculated), lobsters at one of the islands declined to extinction. Both islands were later closed to fishing. Barkai \& McQuaid (1988) found that the rocky benthos at the island with lobsters supported a lush kelp forest, and that lobsters made up about 70 percent of the macroinvertebrate biomass. In contrast, the rocky benthos at the island lacking lobsters was dominated by a dense subtidal mussel bed and abundant populations of several species of predatory whelks. Laboratory and field experiments suggested that lobster predation on mussels and whelks was probably responsible for the observed differences between these communities. In an effort to test this hypothesis, Barkai \& McQuiad (1988) translocated 1000 lobsters to the island where they had become extinct. Remarkably, the predatory whelks attacked and consumed all of the lobsters. This study demonstrated a wholly unexpected role switching between predator and prey after the local extinction or reduction of lobsters. Presumably the loss or reduction of lobsters drove the system to an alternate stable state (sensu Lewontin 1969; Sutherland 1974), from which there is no obvious means or likelihood of recovery, even when lobsters are reestablished and protected from fishing.

\section{Conclusions}

It is probably true that few marine species are globally extinct because of human activities, although a number have come close. On the other hand, there are numerous examples of human-caused local extinctions, and due largely to commercial and recreational fisheries, there probably are few marine systems in which some species have not been reduced to such low levels that their ecological importance is either insignificant or drastically altered. Unfortunately, although populations of numerous potentially important species have been recently reduced in kelp forest communities, usually little or nothing is known of the ecological consequences of these reductions. A few other examples include giant sea bass (Stereolepsis gigas), California sheephead (Semicossyphus pulcher), lingcod (Ophiodon elongatus), and rock crabs (Cancer spp.) in the North Pacific, American lobsters (Homarus americanus) in the North Atlantic, and loco (Concbolepis con- cholepis) in the South Pacific. The ecological importance of these species is almost entirely unknown, except for the California sheephead (e.g., Tegner \& Dayton 1981; Cowen 1983), the American lobster (Mann 1973; Breen \& Mann 1976; but see Pringle et al. 1982; Miller 1985), and the loco (Castilla \& Duran 1985; Castilla \& Paine 1987; Duran et al. 1987; Moreno et al. 1986).

From what is known in several specific cases, we offer the following conclusions about the ecology of extinctions in kelp forest ecosystems:

(1) Some consumers have broad influence in kelp forest ecosystems: Extinction of these species, whether global, local, or ecological, may have had profound, complex, and unexpected consequences.

(2) In some instances these interactions may have been important over evolutionary time in shaping the life histories of associated species. We have speculated, in one such possible example, that predators on herbivorous macroinvertebrates influenced the evolution of defense strategies in the kelps. Evolutionary interactions of this sort no doubt have affected both the character of extant communities and the consequences of extinctions.

(3) These ecological and evolutionary effects, and their mechanisms, are best understood where local extinctions have occurred. In particular, such understanding has been derived by comparing areas where populations are extinct with those where they are not, or by watching areas recover from local extinction. The consequences of global extinctions probably will always remain poorly understood. Steller's sea cow is an exemplary case: although these animals probably were abundant in North Pacific kelp forest communities, and thus probably ate large quantities of kelp and other macroalgae, the ecological and evolutionary consequences of this interaction, though possibly very important, are largely a matter of speculation. Similarly, little is known about the consequences of most ecological extinctions. One difficulty is that most population reductions occurred before scuba permitted extensive observation or data acquisition from underwater communities, and at present there are no obvious comparisons in space or time from which the effects of population reductions might be evaluated. However, in some instances there is hope of better understanding ecological extinctions if changes that occur after the cessation of human exploitation are carefully documented. The sea otter in the eastern North Pacific and the loco in the eastern South Pacific provide good examples of the power of this approach.

(4) Because of behavioral or ecological barriers, local extinctions and their ecological consequences may not be simply reversible through protection or species reintroductions. We have found with sea otters that even though habitat may be suitable for reestablishing the 
species, reintroductions are difficult because of individuals' fidelity for an established home range. With the South African spiny lobster, role reversal between predator and prey seems to have rendered the community wholly unsuitable for reestablishing lobsters once they were absent from an area long enough for their prey populations to increase substantially. In instances where recovery of a locally or ecologically extinct species is possible, there may be ecological barriers to reestablishment of the natural community. Kelp forest ecosystems in the western Aleutian Islands provide one such example. Because of frequent sea urchin recruitment and prey selection by sea otters of the larger urchins, habitats deforested of kelp beds by urchin grazing persist for long periods, despite the reestablishment and growth of sea otter populations. Kelp populations eventually become reestablished, but this may require decades. In other regions, where sea urchin recruitment events are rare, kelp beds recover almost immediately after the reestablishment of sea otters. Finally, there may be behavioral or ecological barriers to the reestablishment of an original or natural population equilibrium density. Indications of such subtle and complex processes again come from studies of sea otters. We have speculated that piscivory in this species may be necessary to support the high-density populations that occur at certain islands in the central and western Aleutian archipelago. Conceivably, piscivorous foraging tactics, which may have been lost to sea otters during an extended period when invertebrates were common and fish rare, need to be rediscovered before high equilibrium density populations can be reattained.

Although some of our suggestions are admittedly speculative, they indicate that conservation strategies may involve substantially more complex processes than those imagined in the typically simple constructs of natural resource management.

\section{Acknowledgments}

We are grateful to the many people who have assisted us through the years with fieldwork in the Aleutian Islands, southeast Alaska, and California. We thank the Alaska Maritime National Wildlife Refuge for field support in the Aleutian Islands; the U.S. Coast Guard for transporting personnel and equipment to remote sites in the North Pacific; the National Park Service for support and ship time in southeast Alaska; and the U.S. Navy for access to San Nicolas Island. Funding was provided by the U.S. Fish and Wildlife Service and by NSF Grant No. DPP 8421362.

\section{Literature Cited}

Barkai, A., and C. McQuaid. 1988. Predator-Prey role reversal in a marine benthic ecosystem. Science 242:62-64.
Berggren, W. A., and J. A. VanCouvering, editors. 1984. Catastrophies and earth history. Princeton University Press, Princeton, New Jersey.

Bodkin, J. L. 1988. Effects of kelp forest removal on associated fish assemblages in central California. Journal of Experimental Marine Biology and Ecology 117:227-238.

Bonner, J. T. 1980. The evolution of culture in animals. Princeton University Press, Princeton, N.J. 216 pp.

Boyer, D. A., and R. D. Brown. 1988. A survey of translocation of mammals in the United States 1985. Pages 1-11 in L. Nielsen and R. D. Brown, editors. Translocation of wild animals. Wisconsin Humane Society and Caesar Kleberg Wildlife Research Institute, Milwaukee, Wisconsin, and Kingsville, Texas. $333 \mathrm{pp}$

Breen, P. A., and K. H. Mann. 1976. Changing lobster abundance and the destruction of kelp beds by sea urchins. Marine Biology 34:137-142

Brownell, R. L., Jr., and G. B. Rathbun. 1988. California sea otter translocation: a status report. Endangered Species Technical Bulletin 13(4);1,6. U.S. Fish and Wildlife Service, Washington, D.C.

Castilla, J. C., and L. R. Duran. 1985. Human exclusion from the rocky intertidal zone of central Chile: the effects on Concholepas concbolepas (Gastropoda). Oikos 45:391-399.

Castilla, J. C., and R. T. Paine. 1987. Predation and community organization on Eastern Pacific, temperate zone, rocky intertidal shores. Revista Chilena de Historia Natural 60:131-151.

Caughley, G. 1977. Analysis of vertebrate populations. John Wiley and Sons, New York. 234 pp.

Cowen, R. K 1983. The effect of sheephead (Semicossypbus pulcber) predation on red sea urchin (Strongylocentrotus franciscanus) populations: an experimental analysis. Oecologia 58:249-255.

Dayton, P. K 1973. Dispersion, dispersal and persistence of the annual intertidal alga Postelsia palmaeformis Ruprecht. Ecology 54:433-438.

Dayton, P. K 1975a Experimental studies of algal canopy interactions in a sea otter-dominated kelp community at Amchitka Island, Alaska. U.S. National Marine Fisheries Service Fisheries Bulletin 73:230-237.

Dayton, P. K 1975b. Experimental evaluation of ecological dominance in a rocky intertidal algal community. Ecological Monographs 45:137-159.

Dayton, P. K., V. Currie, T. Gerrodette, B. D. Keller, R. Rosenthal, and D. Ven Tresca. 1984. Patch dynamics and stability of some California kelp communities. Ecological Monographs 54:253-289.

Domning, D. P. 1972. Steller's sea cow and the origin of North Pacific aboriginal whaling. Syesis 5:187-189.

Domning, D. P. 1978. Sirenian evolution in the North Pacific Ocean. University of California Publications in Geology 118:1$176+18$ plates. 
Druehl, L. D. 1969. The northeast Pacific rim distribution of the Laminariales. International Seaweed Symposium Proceedings 6:161-170.

Duffy, J. M. 1973. The status of the California spiny lobster fishery. California Department of Fish and Game, Marine Resources Technical Report 10:1-15.

Duggins, D. O. 1980 . Kelp beds and sea otters: an experimental approach. Ecology 61:447-453.

Duggins, D. O. 1988. The effects of kelp forests on nearshore environments: biomass, detritus, and altered flow. Pages 192201 in G. R. VanBlaricom and J. A. Estes, editors. The community ecology of sea otters. Springer-Verlag, Berlin, East Germany.

Duggins, D. O., C. A. Simenstad, and J. A. Estes. 1989. Magnification of secondary production by kelp detritus in coastal marine ecosystems. Science 245:170-173.

Duran, L. R., J. C. Castilla, and D. Oliva. 1987. Intensity of human predation on rocky shores at Las Cruces, central Chile. Environmental Conservation 14:143-149.

Ebeling, A. W., and D. R. Laur. 1988. Fish populations in kelp forests without sea otters: effects of severe storm damage and destructive sea urchin grazing. Pages 169-191 in G. R. VanBlaricom and J.A. Estes, editors. The community ecology of sea otters. Springer-Verlag, Berlin, East Germany.

Estes, J. A. 1981. The case of the sea otter. Pages 167-180 in P. Jewell and S. Holt, editors. Problems in management of locally abundant wild mammals. Academic Press, New York.

Estes, J. A., R. J. Jameson, and A. M. Johnson. 1981. Food selection and some foraging tactics of sea otters. Pages 606-641 in J. A. Chapman and D. Pursley, editors. The worldwide furbearer conference proceedings. Worldwide Furbearer Conference, Inc., Frostburg, Maryland.

Estes, J. A., R. J. Jameson, and E. B. Rhode. 1982. Activity and prey selection in the sea otter: influence of population status on community structure. American Naturalist 120:242-258.

Estes, J. A., and J. F. Palmisano. 1974. Sea otters: their role in structuring nearshore communities. Science 185:1058-1060.

Estes, J. A., N. S. Smith, and J. F. Palmisano. 1978. Sea otter predation and community organization in the western Aleutian Islands, Alaska. Ecology 59:822-833.

Estes, J. A., and P. D. Steinberg. 1988. Predation, herbivory, and kelp evolution. Paleobiology 14:19-36.

Estes, J. A., and G. R. VanBlaricom. 1985. Sea-otters and shellfisheries. Pages 187-235 in J. R. Beddington, R. J. H. Beverton, and D. M. Lavigne, editors. Marine mammals and fisheries. George Allen and Unwin, London.

Estes, J. A. Manuscript. Growth and equilibrium in sea otter populations.

Foster, M. S., and D. R. Schiel. 1988. Kelp communities and sea otters: keystone species or just another brick in the wall? Pages 92-108 in G. R. VanBlaricom and J. A. Estes, editors. The com- munity ecology of sea otters. Springer-Verlag, Berlin, East Germany.

Garshelis, D. L., J. A. Garshelis, and A. T. Kimker. 1986. Sea otter time budgets and prey relationships in Alaska. Journal of Wildlife Management 50:637-647.

Harrold, C., and J. S. Pearse. 1987. The ecological role of echinoderms in kelp forests. Pages 137-233 in M. Jangoux and J. M. Lawrence, editors. Echinoderm Studies, A. A. Balkema, Rotterdam, the Netherlands.

Irons, D. B., R. G. Anthony, and J. A. Estes. 1986. Foraging strategies of Glaucous-winged Gulls in a rocky intertidal community. Ecology 67:1460-1474.

Jameson, R. J., K W. Kenyon, A. M. Johnson, and H. M. Wight. 1982. History and status of translocated sea otter populations in North America. Wildlife Society Bulletin 10:100-107.

Jameson, R. J., K. W. Kenyon, S. Jefferies, and G. R. VanBlaricom. 1986. Status of a translocated sea otter population and its habitat in Washington. Murrelet 67:84-87.

Kenyon, K. W. 1969. The sea otter in the eastern Pacific Ocean. North American Fauna 68:1-352.

Laur, D. R., A. W. Ebeling, and D. A. Coon. 1988. Effects of sea otter foraging on subtidal reef communities off central California. Pages 151-167 in G. R. VanBlaricom and J.A. Estes, editors. The community ecology of sea otters. Springer-Verlag, Berlin, East Germany.

Lawrence, J. M. 1975. On the relationships between marine plants and sea urchins. Oceanography and Marine Biology Annual Review 13:213-286.

Lewontin, R. C. 1969. The meaning of stability. Brookhaven Symposia in Biology 22:13-24.

Lyons, K. J. 1989. Individual variation in diet in the female California sea otter, Enbydra lutris. M.S. thesis. University of California, Santa Cruz. 40 pp.

Mann, K. H. 1973. Seaweeds: their productivity and strategy for growth. Science 182:975-981.

Mann, K. H. 1982. Ecology of coastal waters. University of California Press, Berkeley, California.

Marsh, H. 1982. Analysis of stomach contents of dugongs from Queensland. Australian Wildlife Research 9:55-67.

Martin, P. S. 1973. The discovery of America. Science 179:969-974.

Martin, P. S., and R. G. Klein, editors. 1984. Quarternary extinctions. A prehistoric revolution. University of Arizona Press, Tucson.

Miller, R. J. 1985. Seaweeds, sea urchins, and lobsters: a reappraisal. Canadian Journal of Fisheries and Aquatic Science 42:2061-2072.

Moreno, C. A., K. M. Lunecke, and M. I. Lepez. 1986. The response of an intertidal Concholepas concbolepas (Gastropoda) population to protection from man in southern Chile 
and the effects of benthic sessile assemblages. Oikos 46:359364.

Paine, R. T. 1979. Disaster, catastrophe and local persistence of the sea palm Postelsia palmaeformis. Science 205:685-687.

Paine, R. T. 1980. Food webs: linkage, interaction strength, and community infrastructure. Journal of Animal Ecology 46:667685.

Pringle, J. D., G. J. Sharp, and J. F. Caddy. 1982. Interactions in kelp bed ecosystems in the northwest Atlantic: a review of a workshop. Pages 108-115 in M. C. Mercer, editor. Multispecies approaches to fisheries management advice. Canadian Special Publications in Fisheries and Aquatic Sciences. 59.

Quast, J. C. 1971a. Fish fauna of the rocky inshore zone. Nova Hedwigia 32:481-507.

Quast, J. C. 1971b. Estimates of the populations and the standing crop of kelp bed fishes. Nova Hedwigia 32:509-540.

Reed, D. C., and M. S. Foster. 1984. The effects of canopy shading on algal recruitment and growth in a giant kelp forest. Ecology 65:937-948.

Riedman, M., and J.A. Estes. Manuscript. Biology of the sea otter. A review.

Robles, C. 1987. Predator foraging characteristics and prey population structure on a sheltered shore. Ecology 68:15021514.

Rogers, L. L. 1988. Homing tendencies of large mammals: a review. Pages 76-92 in L. Nielsen and R. D. Brown, editors. Translocation of wild animals. Wisconsin Humane Society and Caesar Kleberg Wildlife Research Institute. Milwaukee, Wisconsin, and Kingsville, Texas. 333 pp.

Simenstad, C. A., J. A. Estes, and K. W. Kenyon. 1978. Aleuts, sea otters, and alternate stable-state communities. Science 200:403-411.

Sousa, W. P. 1979. Experimental investigations of disturbance and ecological succession in a rocky intertidal algal community. Ecological Monographs 49:227-254.
Steinberg, P.D. 1985. Feeding preferences of Tegula funebra. lis and chemical defenses of marine brown algae. Ecological Monographs 55:333-349.

Steinberg, P. D. 1989. Biogeographical variation in brown algal polyphenolics and other secondary metabolites: comparison between temperate Australasia and North America. Oecologia 78:373-382.

Stejneger, L. 1887. How the great northern sea-cow (Rytina) became exterminated. American Naturalist 21:1047-1054.

Sutherland, J.P. 1974. Multiple stable points in natural communities. American Naturalist 108:859-873.

Takahashi, S., D. P. Domning, and T. Saito. 1986. Dusisiren dewana n. sp. (Mammalia:Sirenia), a new ancestor of Steller's sea cow from the Upper Miocene of Yamagata prefecture, northeastern Japan. Transactions and Proceedings of the Palaeontological Society of Japan 141:293-321.

Tegner, M. J., and P.K Dayton. 1981. Population structure, recruitment and mortality of two sea urchins (Strongylocentrotus franciscanus and $S$. purpuratus) in a kelp forest. Marine Ecology Progress Series 5:255-268.

Tegner, M. J., and L. A. Levin. 1983. Spiny lobsters and sea urchins: analysis of a predatory-prey interaction. Journal of Experimental Marine Biology and Ecology 73:125-150.

Valentine, J. W., editor. 1985. Phanerozoic diversity patterns. Princeton University Press, Princeton, N.J.

VanBlaricom, G. R., and J. A. Estes, editors. 1988. The community ecology of sea otters. Springer-Verlag, Berlin, East Germany.

Wendell, F. E., R. A. Hardy, J. A. Ames, and R. T. Burge. 1986. Temporal and spatial patterns in sea otter (Enbydra lutris) range expansion and in the loss of the Pismo clam fisheries. California Fish and Game 72:197-212.

Wilson, E. O. 1975. Sociobiology: the new synthesis. The Belknap Press, Cambridge, Massachusetts. 697 pp. 